\title{
Assessing the Immune Response When Raising Antibodies for Use in Xenopus
}

\author{
Maya Z. Piccinni and Matthew J. Guille ${ }^{1}$ \\ European Xenopus Resource Centre, Institute of Biological and Biomedical Sciences, University of Portsmouth, \\ Portsmouth, Hampshire PO1 2DY, United Kingdom
}

Frog-specific antibodies usually must be raised for work in Xenopus. Selecting a host animal whose immune system will respond to a target antigen with an antibody response is essential to obtaining high-quality antibodies. To determine whether an immunized animal has produced antibodies against an antigen, western blotting using Xenopus embryo or egg extract as the protein source can be performed as described here. When a protein of the expected size is detected by western blotting in the immune sera but not the preimmune sera, the antibody has been successfully raised.

It is essential that you consult the appropriate Material Safety Data Sheets and your institution's Environmental Health and Safety Office for proper handling of equipment and hazardous materials used in this protocol.

RECIPES: Please see the end of this protocol for recipes indicated by $<R>$. Additional recipes can be found online at http://cshprotocols.cshlp.org/site/recipes.

1,1,1-trichlorotrifluorethane (optional; see Step 4)

Antibodies (select one of the following; see Steps 13-14)

Primary antibody (HRP-conjugated)

Primary antibody (unconjugated) and species-appropriate HRP-conjugated secondary antibody See Protocol: Raising Antibodies for Use in Xenopus (Piccinni and Guille 2020a). To reduce background on the western blot, the antibodies can be purified as described in Protocol: Purifying Antibodies Raised against Xenopus Peptides (Piccinni and Guille 2020b).

Blocking buffer (select one of the following based on empirical testing)

1\% Blocking Reagent (Roche 11096176001) in maleic acid buffer (100 mm maleic acid, $150 \mathrm{~mm}$ $\mathrm{NaCl})$

5\% BSA (Fisher Scientific BPE9701) in TBSTw

$5 \%(\mathrm{w} / \mathrm{v})$ nonfat dry milk (Marvel) in TBSTw

Some blocking buffers work better than others for certain antibodies.

$\mathrm{dH}_{2} \mathrm{O}$

\footnotetext{
${ }^{1}$ Correspondence: matthew.guille@port.ac.uk From the Xenopus collection, edited by Hazel L. Sive.

(c) 2020 Cold Spring Harbor Laboratory Press

Cite this protocol as Cold Spring Harb Protoc; doi:10.1101/pdb.prot105593
} 
Equipment

Heating block at $95^{\circ} \mathrm{C}$

ImageQuant LAS4000 or equivalent

Microcentrifuge (at room temperature or at $4^{\circ} \mathrm{C}$; see Step 4)

Microcentrifuge tubes

Micropipette with $200-\mu \mathrm{L}$ tip (see Step 3)

Nitrocellulose membrane

Rocker

SDS-PAGE equipment (see Step 7)

Vortex

Western blotting equipment (see Steps 8-10)

Whatman 3 MM paper or equivalent

Detailed western blotting protocols are available (e.g., Mahmood and Yang 2012). The advantages of including a positive control antigen and purifying antibodies are clearly seen in Figure 1. It is difficult to identify the additional band in the immune serum before purification but nonetheless the response is clear (compare the antigen lanes in the preimmune and immune samples).

\section{Embryo Extract Preparation}

1. Remove all buffer from each microcentrifuge tube containing a set of 10 embryos. As a general rule of thumb, use two embryos per lane of the gel.

2. Add $150 \mu \mathrm{L}$ of EB supplemented with cOmplete EDTA-free protease inhibitor cocktail tablets to each set of 10 embryos.

3. Manually disrupt the embryos by pipetting them up and down with $200-\mu \mathrm{L}$ tip until the solution is homogeneous.

At this point, the homogenate can be stored at $-80^{\circ} \mathrm{C}$ if necessary.

4. Extract the proteins with or without 1,1,1-trichlorotrifluorethane as follows. Keep in mind that yolk solubility may be increased if 1,1,1-trichlorotrifluorethane extraction is omitted. 
M.Z. Piccinni and M.J. Guille

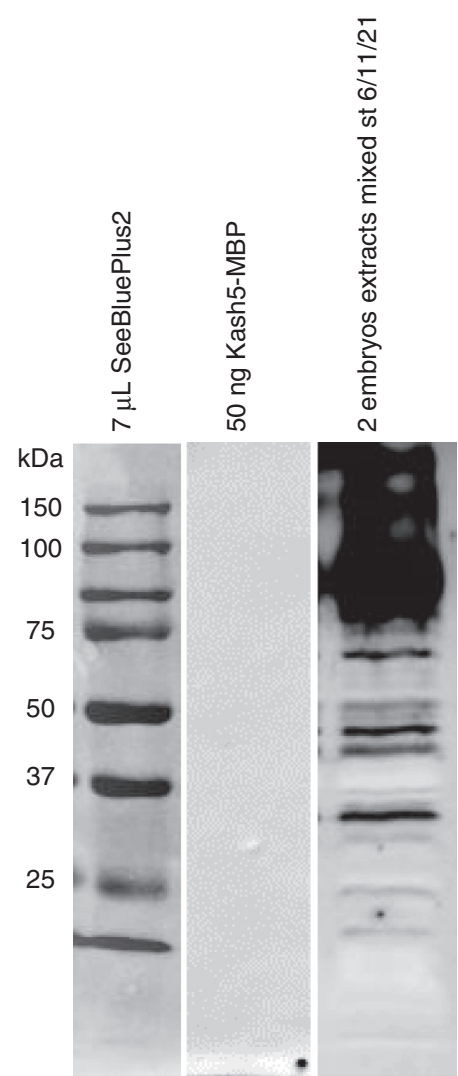

Control Preimmune
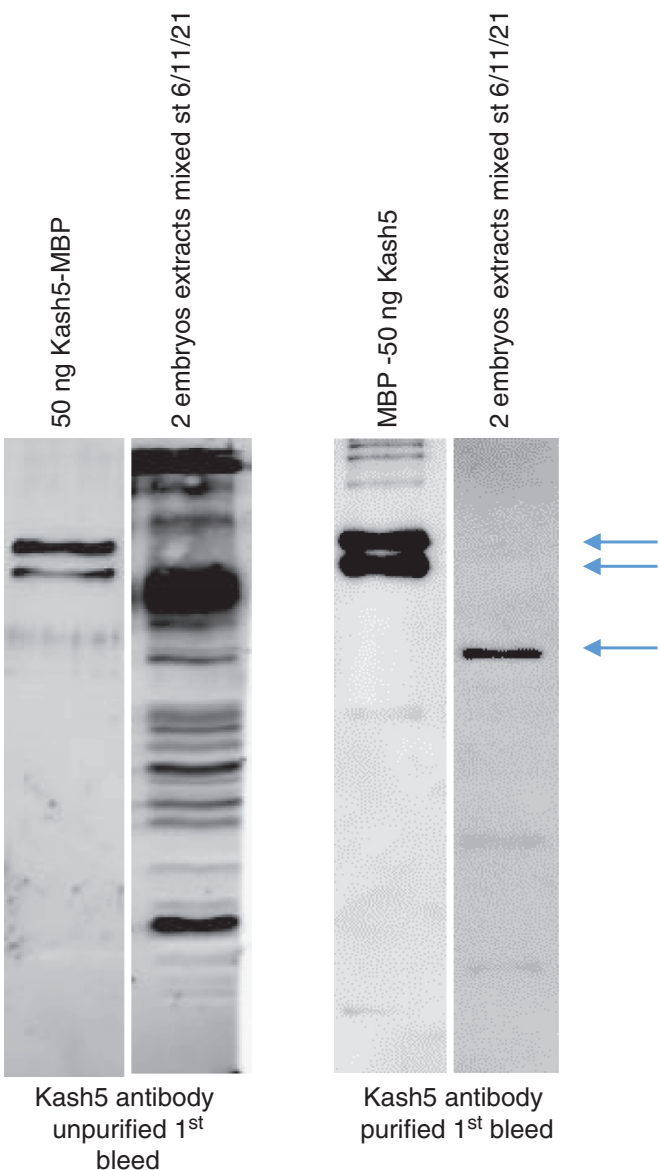

FIGURE 1. Western blot to test a purified Kash5 antibody. The three gels were run and treated under the same conditions, the only variable being the primary antibody used. Proteins from embryos at stages 6, 11, and 21 were isolated and run using extracts from two embryos per lane. The positive control, an MBP-Kash5 protein expressed in E.coli (calculated MW approximately $90 \mathrm{kDa}$ ) runs as two major bands at 90-95 kDa (upper arrows) while the native Kash 5 from embryo extract runs as a single band at $59 \mathrm{kDa}$ (lower arrow). The latter is only detected as a unique, clear band once the immune serum has been purified using the unpurified and purified forms of the antibody. MBP-Kash5 is not seen when the preimmune serum was used. The high background levels observed before purification of the antibody were minimized and Kash5 (bottom arrow at $59 \mathrm{kDa}$ ) was detected as a single protein of the correct size once the antibody was purified.

\section{Extraction with 1,1,1-Trichlorotrifluorethane}

i. Add an equal volume of 1,1,1-trichlorotrifluorethane, and vortex very thoroughly.

ii. Centrifuge at $16,000 \mathrm{~g}$ in a microcentrifuge for $5 \mathrm{~min}$ at room temperature.

\section{Extraction without 1,1,1-Trichlorotrifluorethane}

iii. Centrifuge the lysate at $16000 \mathrm{~g}$ for $30 \mathrm{~min}$ at $4^{\circ} \mathrm{C}$.

iv. Aspirate the lipid layer from the top of the clear lysate.

5. Pipette the clear top layer $(\sim 200 \mu \mathrm{L})$, which contains yolk-depleted protein extract, and place it in a fresh tube.

6. Add one of the gel-loading solutions to a final concentration of $1 \times$. Incubate for $3 \mathrm{~min}$ at $95^{\circ} \mathrm{C}$.

7. Immediately separate the proteins by SDS-PAGE using any standard procedure.

Alternatively, store the protein extracts at $-80^{\circ} \mathrm{C}$ until use. 
Membrane Transfer

8. Insert the following items into the western blot holder in order:

i. a fiber pad,

ii. two Whatman 3MM paper pads,

iii. the gel,

iv. the nitrocellulose membrane,

v. two Whatman $3 \mathrm{MM}$ paper pads covering the membrane, and

vi. another fiber pad.

9. Place the "sandwich" into the tank, ensuring that the gel is on the negative side, and fill the tank with western transfer buffer.

10. Transfer proteins at $30 \mathrm{~mA}$ overnight or at $300 \mathrm{~mA}$ for $2 \mathrm{~h}$.

Membrane Blocking

11. Wash the nitrocellulose membrane with $\mathrm{dH}_{2} \mathrm{O}$ for 5 min at room temperature.

12. Incubate the membrane in $25 \mathrm{~mL}$ of the blocking buffer of choice for $1 \mathrm{~h}$ at room temperature or overnight at $4^{\circ} \mathrm{C}$.

Antibody Incubations

13. Replace the blocking buffer with fresh blocking buffer containing the primary antibody at the appropriate dilution. Incubate with gentle agitation for $1-2 \mathrm{~h}$ at room temperature or overnight at $4^{\circ} \mathrm{C}$.

Serial dilutions of the new antibody can be used to determine the appropriate concentration.

14. Wash the membrane as follows depending on if the primary antibody is unconjugated or conjugated to a label. Conduct all membrane washing steps at room temperature.

\section{For Unconjugated Primary Antibodies}

i. Wash the membrane three times for 5 min each with $10-15 \mathrm{~mL}$ of TBSTw.

ii. Incubate the membrane with fresh blocking buffer containing the species-appropriate HRPconjugated secondary antibody according to the manufacturer's recommended dilution with gentle agitation for $1 \mathrm{~h}$.

For example, a 1:2000 dilution is used for the Anti-Rabbit IgG-Peroxidase conjugated secondary antibody (Sigma-Aldrich A0545).

iii. Wash the membrane twice for $5 \mathrm{~min}$ each with $15 \mathrm{~mL}$ of blocking solution.

iv. Wash once for 5 min with TBSTw.

v. Rinse once with PBS for 5 min.

\section{For HRP-Conjugated Primary Antibodies}

vi. Wash the membrane twice for 5 min each with $15 \mathrm{~mL}$ of blocking solution.

vii. Wash the membrane once for 5 min with TBSTw.

viii. Rinse once with PBS for 5 min. 
M.Z. Piccinni and M.J. Guille

Protein Detection

15. Incubate the membrane at room temperature for $1 \mathrm{~min}$ with $10 \mathrm{~mL}$ of ECLI buffer and $10 \mathrm{~mL}$ of ECLII buffer.

Alternatively, incubate the membrane at room temperature for 5 min with $7 \mathrm{~mL}$ Clarity Western ECL Substrate Solution A and $7 \mathrm{~mL}$ of Clarity Western ECL Substrate Solution B.

16. Visualize using an ImageQuant LAS4000 or equivalent following the manufacturer's instructions, varying the exposure from $1 \mathrm{sec}$ to $10 \mathrm{~min}$ as necessary.

See Troubleshooting.

\section{TROUBLESHOOTING}

Problem (Step 16): The proteins were not fully denatured prior to running the gel, causing bands to be seen at twice or three times the size of the monomer on the membrane.

Solutions: The ability of the proteins to denature under particular conditions varies. Both the loading buffer and denaturing temperature can be optimized. The $2 \times$ SDS loading dye or $2 \times \beta$-mercaptoethanol sample buffer are commonly used. Potential temperature treatments include for $3 \mathrm{~min}$ at $95^{\circ} \mathrm{C}, 20 \mathrm{~min}$ at $55^{\circ} \mathrm{C}$, and the combination of $20 \mathrm{~min}$ at $55^{\circ} \mathrm{C}$ followed by for $3 \mathrm{~min} 95^{\circ} \mathrm{C}$.

Problem (Step 16): The antibody concentration was not optimized, causing the western blot to have high background.

Solutions: To obtain a clear and low-background western blot, optimize the antibody concentration as follows.

1. Adjust the gel's comb so that there are only two lanes, a single well for the size marker and a joint, long well containing the sample.

2. Run the gel and transfer as normal.

3. After transfer, cut the membrane containing the sample proteins into strips, leaving the first strip to contain the size marker and some of the sample.

4. Incubate the first strip with the preimmune serum.

5. Incubate the rest of the strips under the same conditions but with varying antibody concentrations.

Problem (Step 16): The antibody stability was poor, resulting in western blot results that were unclear or not reproducible.

Solutions: Avoid freeze-and-thaw cycles. Store the antibody lyophilized at $-20^{\circ} \mathrm{C}$ for long-term storage (years) and at $4^{\circ} \mathrm{C}$ for short-term storage (weeks/months). Purified antibodies tend to be more stable than the raw serum; therefore, purification of serum is suggested if results with raw serum vary.

To determine whether an immunized animal has produced antibodies against an antigen, western blotting (Mahmood and Yang 2012) or an ELISA (Hornbeck 1992) are performed. Further information on the effectiveness of the antibody is then obtained by determining fixation conditions on cultured cells expressing the antigen. The final test of the antibody is by immunohistochemistry on embryos or tissue sections (see Protocol: Whole-Mount Fluorescence Immunocytochemistry on Xenopus Embryos [Lee et al. 2008]). Detected protein size is not provided by the ELISA, so western blotting, which has been made more quantitative with fluorescent secondary antibodies and fluorescence readers, is described here. 
$2 \times \boldsymbol{\beta}$-Mercaptoethanol Sample Buffer

100 mm Tris- $\mathrm{HCl}, \mathrm{pH} 6.8$

$2 \%$ SDS

$4 \% \beta$-mercaptoethanol

$20 \%$ glycerol

$0.01 \%$ bromophenol blue

Store for up to $1 \mathrm{yr}$ at $20^{\circ} \mathrm{C}$.

ECLII Buffer for Chemiluminescent Detection of HRP-Conjugated Antibodies

$0.021 \%$ Hydrogen peroxide

$10 \mathrm{~mm}$ Tris, $\mathrm{pH} 8.5$

Store for up to $1 \mathrm{yr}$ at $4^{\circ} \mathrm{C}$.

ECLI Buffer for Chemiluminescent Detection of HRP-Conjugated Antibodies

$2.5 \mathrm{~mm}$ luminol

$0.9 \mathrm{~mm}$ p-coumaric acid

$10 \mathrm{~mm}$ Tris, $\mathrm{pH} 8.5$

Store for up to $1 \mathrm{yr}$ at $4^{\circ} \mathrm{C}$.

Embryo Buffer for Testing Antibodies (EB)

$20 \mathrm{~mm}$ HEPES (pH 7.9)

$2 \mathrm{mM} \mathrm{MgCl}_{2}$

$10 \mathrm{~mm} \beta$-glycerophosphate

$2 \mathrm{~mm}$ levamisole

Store for up to $3 \mathrm{mo}$ at $20^{\circ} \mathrm{C}$.

SDS Protein Sample Buffer (2x)

0.125 м Tris- $\mathrm{HCl}, \mathrm{pH} 6.8$

$4 \%$ SDS

0.15 м DTT

$20 \%$ glycerol

$0.01 \%$ bromophenol blue

Store for up to $1 \mathrm{yr}$ at $20^{\circ} \mathrm{C}$.

Tris-Buffered Saline with Detergent (TBSTw) for Western Blotting

$20 \mathrm{~mm}$ Tris

$150 \mathrm{~mm} \mathrm{NaCl}$

$0.1 \%$ Tween 20

Store at room temperature for up to 2 mo. 
M.Z. Piccinni and M.J. Guille

\section{Western Blotting Transfer Buffer}

$200 \mathrm{~mm}$ Tris base

$150 \mathrm{~mm}$ glycine

$0.1 \%$ SDS

$20 \%$ methanol

Make fresh.

\section{REFERENCES}

Hornbeck P. 1992. Enzyme-linked immunosorbent assays. Curr Protoc Immunol 1: 2.1.1-2.1.22. doi:10.1002/0471142735.im0201s01

Lee C, Kieserman E, Gray RS, Park TJ, Wallingford J. 2008. Whole-mount fluorescence immunocytochemistry on Xenopus embryos. Cold Spring Harb Protoc doi:10.1101/pdb.prot 4957

Mahmood T, Yang P-C. 2012. Western blot: technique, theory, and trouble shooting. N Am J Med Sci 4: 429-434. doi:10.4103/1947-2714 .94940

Owens NDL, Blitz IL, Lane MA, Patrushev I, Overton JD, Gilchrist MJ, Cho KWY, Khokha MK. 2016. Measuring absolute RNA copy numbers at high temporal resolution reveals transcriptome kinetics in development. Cell Rep 14: 632-647. doi:10.1016/j.celrep.2015.12.050
Peshkin L, Wühr M, Pearl E, Haas W, Freeman RM Jr, Gerhart JC, Klein AM, Horb M, Gygi SP, Kirschner MW. 2015. On the relationship of protein and mRNA dynamics in vertebrate embryonic development. Dev Cell 35: 383-394. doi:10.1016/j.devcel.2015.10.010

Piccinni MZ, Guille MJ. 2020a. Raising antibodies for use in Xenopus. Cold Spring Harb Protoc doi:10.1101/pdb.prot105585

Piccinni MZ, Guille MJ. 2020b. Purifying antibodies raised against Xenopus peptides. Cold Spring Harb Protoc doi:10.1101/pdb.prot105619

Sun L, Bertke MM, Champion MM, Zhu G, Huber PW, Dovichi NJ. 2014. Quantitative proteomics of Xenopus laevis embryos: expression kinetics of nearly 4000 proteins during early development. Sci Rep 4: 4365. doi:10.1038/srep04365 


\section{Assessing the Immune Response When Raising Antibodies for Use in Xenopus}

Maya Z. Piccinni and Matthew J. Guille

Cold Spring Harb Protoc; doi: 10.1101/pdb.prot105593 originally published online January 3, 2020

\begin{tabular}{|c|c|}
\hline $\begin{array}{l}\text { Email Alerting } \\
\text { Service }\end{array}$ & Receive free email alerts when new articles cite this article - click here. \\
\hline $\begin{array}{l}\text { Subject } \\
\text { Categories }\end{array}$ & $\begin{array}{l}\text { Browse articles on similar topics from Cold Spring Harbor Protocols. } \\
\text { Antibodies ( } 119 \text { articles) } \\
\text { Antibodies, general ( } 289 \text { articles) } \\
\text { Generating Antibodies ( } 71 \text { articles) } \\
\text { Generating Antibodies, general (60 articles) } \\
\text { Immunoblotting (51 articles) } \\
\text { Preparation of Cellular and Subcellular Extracts (104 articles) } \\
\text { Xenopus (210 articles) }\end{array}$ \\
\hline
\end{tabular}

